Int. J. Electrochem. Sci., 14 (2019) 1318 - 1330

\title{
Single Step Carbonization-Activation of Durian Shells for Producing Activated Carbon Monolith Electrodes
}

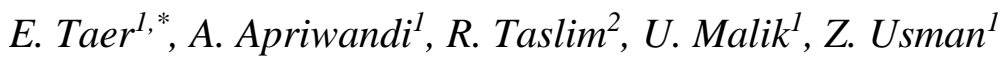 \\ ${ }^{1}$ Department of Physics, University of Riau, 28293 Simpang Baru, Riau, Indonesia. \\ ${ }^{2}$ Department of Industrial Engineering, State Islamic University of Sultan Syarif Kasim, \\ 28293 Simpang Baru, Riau, Indonesia. \\ "E-mail: erman.taer@lecturer.unri.ac.id
}

doi: $10.20964 / 2019.02 .67$

Received: 8 October 2018 / Accepted: 5 December 2018 / Published: 5 January 2019

Four types of monolithic carbon electrodes were prepared from durian shell waste by a one-step carbonization-activation process. The activation process was performed physically at a temperature of $900{ }^{\circ} \mathrm{C}$ for 1 hour. The carbon electrodes were produced with various amounts of (i) $\mathrm{CO}_{2}$ gas and (ii) steam activating agent. For both types of activation processes, the samples also varied according to their electrode particle size, i.e., (a) particles smaller than 38 microns and from to (b) 39 - 52 microns. After varying these four factors, we produced a monolithic carbon electrode with a highest specific capacitance of $130.35 \mathrm{~F} \mathrm{~g} \mathrm{~g}^{-1}$ with the steam activating agent and a particle size of 39-52 microns. The optimized electrochemical properties were evidenced by the physical characteristics, such as the density, specific surface area and surface morphology. The results of this study present a relatively simple process for producing supercapacitor electrodes made from durian shell waste.

Keywords: Durian shells, carbon electrode, specific capacitance, supercapacitor

\section{$\underline{\text { FULL TEXT }}$}

(C) 2019 The Authors. Published by ESG (www.electrochemsci.org). This article is an open access article distributed under the terms and conditions of the Creative Commons Attribution license (http://creativecommons.org/licenses/by/4.0/). 